\title{
Jurist-Diction
}

Volume 3 No. 6, November 2020

\section{Putusan Praperadilan yang Menyatakan Bahwa Hasil Penyidikan yang Telah Selesai Dinyatakan Tidak Sah Ditinjau Dari Undang-Undang No. 8 Tahun 1981 Tentang Hukum Acara Pidana}

\author{
Andika Simamora \\ andika.simamora-2015@fh.unair.ac.id \\ Universitas Airlangga
}

How to cite:

Andika Simamora, 'Putusan

Praperadilan Yang Menyatakan Bahwa Hasil Penyidikan Yang Telah Selesai Dinyatakan Tidak Sah Ditinjau Dari UndangUndang No. 8 Tahun 1981 Tentang Hukum Acara Pidana' (2020) Vol. 3 No. 6 JuristDiction.

Histori artikel:

Submit 1 September 2020 Diterima 22 September 2020; Diterbitkan 1 November 2020.

DOI:

10.20473/jd.v3i6.22954

\begin{abstract}
Abstrak
Praperadilan bukanlah suatu lembaga pengadilan yang berdiri sendiri, melainkan merupakan suatu pemberian wewenang dan fungsi baru yang dilimpahkan oleh Kitab Undang-Undang Hukum Acara Pidana disetiap Pengadilan Negeri, sebagai wewenang dan fungsi tambahan Pengadilan Negeri yang sudah ada.Tujuan hasil penyidikan yang telah selesai merupakan objek dalam Praperadilan dan untuk mengetahui Ratio Decidendi hakim dalam menetapkan hasil penyidikan yang telah selesai dinyatakan tidak sah dan tidak mengikat dalam putusan Praperadilan No. 117/Pid.Prap/2017/PN.Jkt.Sel. Kesimpulan dari penelitian ini adalah penetapan bahwa hasil penyidikan sudah lengkap bukanlah merupakan objek dari Praperadilan, sementara permasalahan bahwa hasil penyidikan sudah lengkap merupakanmasalah terkait substansi perkara dan bukan aspek formil. Kemudian, Ratio Decidendi hakim dalam penetapan hasil penyidikan yang telah selesai dinyatakan tidak sah dan tidak mengikat dalam putusan Praperadilan No. 117/ Pid.Prap/2017/PN.Jkt.Sel berdasarkan pada Putusan Mahkamah Konstitusi Indonesia No. 21/PUU-XII/2014 dan berdasarkan kepada Yurisprudensi Putusan Pengadilan Negeri Jakarta Selatan No. 04/Pid. Prap/2015/PN.Jkt.Sel.

Kata Kunci: Putusan Praperadilan; Hasil Penyidikan; Ratio Dacidendi.
\end{abstract}

\section{Pendahuluan}

Praperadilan adalah lembaga yang lahir guna mengadakan tindakan pengawasan kepada aparat-aparat penegak hukum supaya dalam prakteknya tidak menyalahgunakan wewenang, karena hal tersebut, dalam pelaksanaannya yang diatur pada Kitab Undang-Undang Hukum Acara Pidana. Kegiatan-kegiatan penyidik yang penerapannya bisa berupa, penangkapan maupun penahanan, maka hukum acara pidana melalui beberapa ketentuan yang bersifat memaksa mengesampingkan asas-asas yang diakui secara menyeluruh, yaitu berupa hak akan 
kebebasan seseorang. Hukum acara pidana memberi hak-hak kepada pejabat-pejabat tertentu guna menahan tersangka ataupun terdakwa pada rangka melaksanakan hukum pidana materiil untuk mencapai ketertiban pada masyarakat. ${ }^{1}$

Berdasarkan pengaturannya, hukum pidana dibedakan ke dalam hukum pidana formil dan materiil. Jika hukum pidana materiil terihindar dari perbuatan apa saja yang dapat di hukum, siapa saja yang dapat di hukum, dan apa saja hukuman yang bisa dijatuhkan, maka hukum pidana formil berbicara mengenai bagaimana menegakkan hukum pidana materiil tersebut. Hukum pidana formil pada umunya juga disebut dengan istilah hukum acara pidana. Hukum acara pidana sangat penting eksistensinya guna menjamin, menegakkan dan mempertahankan hukum pidana materiil. ${ }^{2}$

Kitab Undang-Undang Hukum Acara Pidana menyadari bahwa perlu adanya perlindungan terhadap hak-hak asasi tersangka pada tingkat pemeriksaan, penyidikan, dan penuntutan, sehingga dibentuk upaya hukum Praperadilan. Tujuan Praperadilan menurut M. Yahya Harahap adalah untuk melaksanakan "pengawasan horizontal" atas tindakan upaya paksa yang dikenakan terhadap tersangka selama ia berada dalam pemeriksaan, penyidikan, atau penuntutan, agar benar-benar tindakan itu tidak bertentangan dengan ketentuan perundang-undangan. ${ }^{3}$

Praperadilan bukanlah suatu lembaga pengadilan yang berdiri sendiri, antara lain hanyalah suatu pemberian wewenang dan fungsi baru yang dilimpahkan oleh Kitab Undang-Undang Hukum Acara Pidana pada setiap Pengadilan Negeri, untuk wewenang dan fungsi tambahan pada Pengadilan Negeri yang telah ada. Jika sejauh ini wewenang dan fungsi Pengadilan Negeri adalah mengadili dan memutus perkara pidana dan perkara perdata sebagai tugas utama, maka diberi tugas tambahan guna menilai mengenai sah atau tidaknya penahanan, sah atau tidaknya penyitaan, sah atau tidaknya penghentian penuntutan yang telah dilakukan oleh penyidik ataupun

\footnotetext{
1 Ratna Nurul Alfiah, Praperadilan dan Ruang Lingkupnya (Akademika Pressindo 1986).[35].

2 Lilik Mulyadi, Hukum Acara Pidana, Normatif, Teoritis, Praktik, dan Permasalahannya, (Alumni 2007).[1].

3 M. Yahya Harahap, Pembahasan Permasalahan dan Penerapan KUHAP Pemeriksaan Sidang Pengadilan, Banding, Kasasi, dan Peninjauan Kembali (Sinar Grafika 2000).[4].
} 
dilakukan oleh penuntut umum, yang wewenang pemeriksaannya dilimpahkan kepada Praperadilan. ${ }^{4}$ Sedangkan mengenai wewenang praperadilan, dapat dilihat pada pasal 1 butir 10, yang menegaskan, Praperadilan merupakan wewenang Pengadilan Negeri guna memeriksa dan memutus:

1. Tentang sah atau tidaknya suatu penangkapan ataupun penahanan;

2. Tentang sah atau tidaknya penghentian penyidikan ataupun penghentian penuntutan;

3. Permintaan ganti rugi atau rehabilitasi oleh tersangka, keluarganya, pihak lain, atau kuasanya yang perkaranya tidak diajukan ke pengadilan.

Praperadilan yang semakin popular akhir-akhir ini, terutama sejak ada tambahan objek Praperadilan oleh Putusan Mahkamah Konstitusi No. 21/PUU-XII-2014. Dalam putusannya, Mahkamah Agung menjelaskan terkait Pasal 77 Kitab Undang-Undang Hukum Acara Pidana menambahkan objek Praperadilan dengan penetapan tersangka, penyitaan, serta penggeledahan termasuk kedalam objek Praperadilan. Akibat putusan Mahkamah Konstitusi ini, terjadi penumpukan permohonan praperadilan.

Terdapat perkara menarik yang berkaitan dengan praperadilan di sepanajng tahun 2018. Salah satunya adalah kasus Hiendra Soenjoto yang dianggap telah melakukan tindakan pemalsuan akta autentik oleh rekan kerjanya Sdr. Azhar Umar. Hiendra Soenjoto disebut sebagai pemohon dan Kejaksaan Agung disebut sebagai termohon. Pemohon mengajukam permohonan Praperadilan atas adanya laporan polisi sebanyak empat kali dari orang yang sama, yang ditujukan kepada pemohon, yang mengakibatkan ketidakpastian hukum terjadi pada diri pemohon saat ini. Putusan Praperadilan itu dibacakan Hakim tunggal Effendi Muchtar, yang menyatakan bahwa penetapan hasil penyidikan yang telah selesai dinyatakan tidak sah dan tidak mempunyai kekuatan hukum mengikat. Hal ini cukup unik dikarenakan dalam kasus Hiendra Soenjoto putusan praperadilan menyatakan bahwa hasil penyidikan yang telah selesai dinyatakan tidak sah dan tidak memiliki kekuatan hukum mengikat.

${ }^{4}$ ibid. 


\section{Kewenangan Mengadili Praperadilan}

Kewenangan adalah kekuasaan untuk melakukan atau tidak melakukan sesuatu terkait dengan wilayah tugas yang dibebankan. Sebagaimana umumnya setiap kekuasaan apabila tanpa adanya lembaga, mekanisme pengawas atau mekanisme penguji pasti akan terjadi kesewenang-wenangan. Apalagi lembaga Negara yang memiliki kewenangn untuk melakukan upaya-upaya paksa serta dalam keadaan tertentu diperbolehkan melakukan tindakan pembatasaan, bahkan perampasan terhadap kemerdekaan individu maupun benda miliknya, yang apabila tidak diatur secara seksama akan merugikan masyarakat. Praperadilan adalah kewenangan yang dilimpahkan oleh undang-undang kepada hakim Pengadilan Negeri guna melaksanakan fungsi penilaian kepada beberapa hal, yaitu:

1. Menganai sah atau tidaknya suatu penangkapan dan/atau penahanan atas permintaan tersangka atau kerluarganya atau pihak lain atas kuasa tersangka;

2. Mengenai sah atau tidaknya penghentian penyidikan ataupun penuntutan atas demi ditegakkannya hukum dan keadilan;

3. Mengenai permintaan ganti kerugian atau rehabilitasi oleh tersangka, keluarganya, ataupun pihak lain atas kuasanya yang perkaranya tidak diajukan diajukan ke pengadilan;

Pembahan mengenani kewenangan Praperadilan dalam Bab X Kitab Undang-Undang Hukum Acara Pidana mengenai kewenangan Pengadilan untuk mengadili tepatnya diatur dalam Pasal $77 .{ }^{5}$

\section{Pengertian Preperadilan}

Istilah yang digunakan Kitab Undang-Undang Hukum Acara Pidana adalah Praperadilan, yang arti yang harfiahnya berbeda. Pra artinya sebelum atau mendahului, yang berarti Praperadilan sama dengan sebelum pemeriksaan di sidang pengadilan. ${ }^{6}$

5 Maskur Hidayat, 'Pembaharuan Hukum Terhadap Lembaga Praperadilan Melalui Putusan Pengadilan' (2015) Volume 30 No 3Yuridika.[509].

6 Andi Hamzah, Hukum Acara Pidana Indonesia (Sinar Grafika 2013).[1]. 
Praperadilan merupakan suatu Lembaga baru yang diperkenalkan oleh Kitab Undang-Undang Hukum Acara Pidana, dalam Kitab Undang-Undang Hukum Acara Pidana itu sendiri Praperadilan ditempatkan pada Bab X, Bagian Kesatu, merupakan salah satu dari bagian ruang lingkup wewenang mengadili Pengadilan Negeri.

Praperadilan bukanlah suatu lembaga berdiri sendiri. Bukan juga organisasi tingkat Peradilan yang memiliki kewenangan memberikan putusan akhir atas suatu peristiwa pidana. Praperadilan hanya lembaga baru dengan cirinya:

1. Kesatuan yang melekat di Pengadilan Negeri juga sebagai Lembaga Pengadilan, dapat dijumpai pada tingkat Pengadilan Negeri sebagai satuan tugas yang tidak terpisah dari Pengadilan Negeri;

2. Praperadilan tidak berada sejajar, disamping, ataupun diluar dengan Pengadilan Negeri, namun merupakan bagian dari Pengadilan Negeri;

3. Anggota, finansial, dan peralatannya menjadi satu bersama Pengadilan Negeri dan dibawah pembinaan, pengasawan, dan pimpinan Ketua Pengadilan Negeri ${ }^{7}$.

Mahkamah Konstitusi telah menjadikan penetapan tersangka sebagai salah satu objek Praperadilan yang sebelumnya tidak diatur dalam Kitab UndangUndang Hukum Acara Pidana. Pasal 77 Huruf a Kitab Undang-Undang Hukum Acara Pidana dinyatakan inkontitusional bersayarat sepanjang dimaknai termasuk penetapan tersangka, penggeledahan, dan penyitaan. ${ }^{8}$

Praperadilan memiliki tujuan untuk terlaksananya kepentingan pemeriksaan perkara tindak pidana, undang-undang memberikan kewengan pada penyidik serta penuntut umum untuk melaksanakan suatu tindakan upaya paksa yang berupa penangkapan, penahanan, penyitaan, dan lainnya. Tiap-tiap tindakan upaya paksa yang dilakukan oleh pejabat penyidik serta penuntut umum kepada tersangka, didasari oleh perlakuan yang memiliki sifat:

7 M. Yahya Harahap I, Op.Cit.

8 Tri Jata Ayu Pramesti, 'Hakim Tunggal dan Objek Praperadilan Pasca Putusan MK', (Hukum Online, 2015) < $\underline{w w w . h u k u m o n l i n e . c o m}>$ accessed 2 August 2020. 
1. Upaya tindakan paksa yang dibenarkan oleh undang-undang untuk terlaksananya kepentingan pemeriksaan tindak pidana yang disangkakan kepada tersangka.

2. Upaya tindakan paksa yang dibenarkan oleh hukum serta undang-undang, setiap tindakan upaya paksa dengan sendirinya merupakan perampasan kemerdekaan, kebebasan, dan pembatasan terhadap hak asasi tersangka. ${ }^{9}$

Kasus yang dapat diperiksa dan diputus oleh Praperadilan sehubungan dengan tindakan upaya paksa yang dilakukan oleh pejabat penyidik ataupun penuntut umum terhadap tersangka, hal ini terdapat pada Pasal 1 ayat (10) serta Pasal 77 Kitab Undang-Undang Hukum Acara Pidana. Ada beberapa kewenangan Praperadilan yang lain, antara lain memutus ganti kerugian, memeriksa, dan rehabilitasi, telah diatur pada Pasal 95 dan 97 Kitab Undang-Undang Hukum Acara Pidana.

\section{Memeriksa dan Memutus Sah atau Tidaknya Upaya Paksa}

Merupakan wewenang pertama yang diberikan oleh undang-undang kepada Praperadilan, adalah memeriksa dan memutus sah atau tidaknya:

1. Penangkapan

Rumusan penangkapan yang diatur dalam Undang-Undang Hukum Acara Pidana bisa menjadi dasar tindakan penangkapan, bukan undang-undang yang lain, atau jika undang-undang lain yang membolehkan penangkapan, maka undang-undang tersebut harus merujuk kepada Kitab Undang-Undang Hukum Acara Pidana. Semua yang melakukan penangkapan diluar ketentuan tersebut berarti melanggar hukum dan itulah yang disebut oleh dengan kasus penculikan.

Beberapa syarat hukum yang harus dipenuhi dalam melakukan penangkapan, antara lain:

a) Harus ada surat perintah penyidik.

b) Ada surat tugas sesuai dengan wewenang dan kewajibannya sebagai penyelidik, penyidik pembantu, atau selaku penyidik.

c) Surat tugas dan perintah tersebut harus masih berlaku sebelum dilakukannya penangkapan

\footnotetext{
9 M. Yahya Harahap I, Op.Cit.
} 
d) Batas waktu berlakunya surat penangkapan hanya berlaku satu hari, bilamana sudah lewat waktunya maka harus dilanjutkan dengan penahanan atau status hukumnya selaku tertangkap habis dengan sendirinya.

e) Harus sudah ada bukti permulaan yang cukup, sebagai dugaan kuat telah terjadinya tindak pidana. ${ }^{10}$

2. Penahanan.

Dalam Pasal 1 ayat (21) Kitab Undang-Undang Hukum Acara Pidana dinyatakan bahwa penahanan merupakan penempatan tersangka maupun terdakwa ditempat tertentu oleh penyidik, penuntut umum, ataupun hakim dengan penetapannaya, menurut cara yang diatur pada undang-undang ini. Dengan hal tersebut, berarti penahanan dapat dilakukan sejak pada tahap penyidikan, selama dalam wewenang jaksa penuntut umum ataupun dalam rangka pemeriksaan persidangan pengadilan dengan penetapan hakim yang khusus dibuat untuk itu. ${ }^{11}$

\section{Memeriksa Sah atau Tidaknya Penyidikan atau Penghentian Penuntutan}

Memeriksa serta memutus tentang sah atau tidaknya penghentian penyidikan yang dilakukan oleh pejabat penyidik maupun tentang sah atau tidaknya penghentian penuntutan yang dilakukan oleh penuntut umum kepada dirinya. Karena hasil dari penyidikan ataupun penuntutan tersebut tidak memiliki cukup bukti guna diteruskan perkaranya kedepan sidang pengadilan atau apa yang disangkakan kepada tersangka bukanlah suatu kejahatan atau suatu pelanggaran tindak pidana. Oleh karena hal tersebut tidak memungkin untuk diteruskan perkaranya kedepan sidang pengadilan. Alasan lain penghentian yang dilakukan oleh penyidik ataupun penuntut umum disebabkan karena dalam perkara yang disangkakan kepada tersangka terdapat unsur kedaluarsa untuk menuntut. Apabila dalam pemeriksaan penyidikan atau penuntutan dijumpai adanya unsur daluarsa dalam perkara yang sedang diperiksa, wajar saja apabila penyidikan atau penuntutan dihentikan. ${ }^{12}$

10 Nikolas Simanjuntak, Acara Hukum Pidana Dalam Sirkus Hukum (Ghalia Indonesia 2009).[78].

11 ibid.

${ }^{12}$ M. Yahya Harahap I, Op.Cit. 


\section{Berwenang Memeriksa Tuntutan Ganti Rugi}

Pasal 95 Kitab Undang-Undang Hukum Acara Pidana mengatur tentang ganti kerugian yang diajukan oleh tersangka, keluarga, atau penasihat hukumnya kepada Praperadilan, tuntutan ganti kerugian yang diajukan tersangka berdasarkan pada alasan:

1. Karena penangkapan atau penahanan yang tidak sah.

2. Karena penggeledahan atau penyitaan yang bertentangan dengan ketentuan hukum dan undang-undang.

3. Kekeliruan orang yang sebenarnya diperiksa, ditanagkap, atau ditahan.

Misal, pelaku tindak pidana sebenarnya ialah A, tetapi yang diperiksa, ditangkap, dan ditahan adalah B. Selang beberapa hari kemudian penyidik menyadari atas kekeliruannya memeriksa dan menahan B. Dari kekeliruan tersebut, memberikan beberapa hak kepada yang bersangkutan untuk menuntut ganti kerugian kepada Praperadilan.

\section{Memeriksa Permintaan Rehabilitasi}

Praperadilan memiliki wewenang untuk memeriksa serta memutus permintaan rehabilitasi yang telah diajukan oleh tersangka, keluarga, dan penasihat hukumnya atas penangkapan atau penahanan tanpa dasar hukum yang sudah ditentukan oleh undang-undang. Rehabilitasi atas kekeliruan orang maupun hukum yang telah diterapkan, yang perkaranya tidak diajukan kedepan sidang pengadilan

\section{Praperadilan Terhadap Tindakan Penyitaan}

Setiap upaya paksa yang dilaksanakan dalam penegakan hukum mangandung Hak Asasi Manusia. Oleh hal tersebut, haruslah diberikan perlindungan dengan seksama dan hati-hati, sehingga perampasan atasnya harus sesuai dengan "acara yang berlaku" dan "hukum yang berlaku" yang ditinjau dari standar universal maupun dalam Kitab Undang-Undang Hukum Acara Pidana, tindakan upaya paksa, merupakan perampasan Hak Asasi Manusia atau hak privasi perseorangan yang dilakukan penguasa dalam melaksanakan fungsi peradilan dalam sistem peradilan pidana, yang dapat diklarifikasikan sebagai berikut: 
1. Penangkapan;

2. Penahanan;

3. Penggeledahan;

4. Penyitaan, perampasan, pembeslahan. ${ }^{13}$

\section{Objek Praperadilan}

Objek Praperadilan menurut Pasal 77 Kitab Undang-Undang Hukum Acara Pidana. Menjelaskan, Pengadilan Negeri memiliki wewenang untuk memeriksa serta memutus, sesuai dengan ketentuan yang sudah diatur pada Undang-Undang:

1. Tentang sah atau tidak suatu penangkapan, penahanan, dan penghentian penyidikan, atau penghentian penuntutan;

2. Tentang ganti kerugian ataupun rehabilitasi untuk seseorang yang perkara pidananya dihentikan ditingkat penyidikan atau penuntutan.

Adapun objek Praperadilan berdasarkan pada Pasal 2 Peraturan Mahkamah Agung No. 4 Tahun 2016 adalah sebagai berikut:

1. Sah atau tidaknya penangkapan, penahanan, penghentian penyidikan atau penghentian penuntutan, penetapan tersangka, penyitaan dan penggeledahan;

2. Ganti kerugian dan atau rehabilitasi bagi seseorang yang perkara pidananya dihentikan pada tingkat penyidikan atau penuntutan. ${ }^{14}$

\section{Bentuk Putusan Praperadilan}

Pemeriksaan sidang Praperadilan dilakukan dengan acara cepat, dimulai dari penunjukan hakim, kemudian penetapan hari sidang, dilanjtukan pemanggilan para pihak, dan pemeriksaan sidang Praperadilan dilakukan dengan acara cepat, yang bertujuan supaya dapat dijatuhkan putusan paling lama dalam jangka waktu tujuh hari. Oleh karena hal tersebut, maka bentuk putusan Praperadilan cukuplah sederhana tanpa mengurangi sedikitpun isi pertimbangan yang jelas berdasarkan kepada hukum dan undang-undang. Sifat dari putusan Praperadilan yang sederhana

\footnotetext{
13 ibid.

${ }^{14}$ Peraturan Mahkamah Agung Nomor 4 Tahun 2016 tentang Larangan Peninjauan Kembali Putusan Praperadilan.
} 
ini tidak dibenarkan untuk mengurangi dasar-dasar alasan pertimbangan yang utuh dan secara menyeluruh. ${ }^{15}$

Bentuk putusan Praperadilan tidak diatur secara tegas dalam undang-undang. Berdasarkan Ketentuan Pasal 82 Ayat (1) Huruf e, proses pemeriksaan sidang Praperadilan yang dilaksanakan dengan acara cepat. Hal tersebut harus dilakukan secara konsisten dengan bentuk dan pembuatan putusan dalam acara pemeriksaan singkat dan acara pemeriksaan cepat. Bentuk putusan yang telah sesuai dengan proses pemeriksaan cepat, tidak lain daripada putusan yang disatukan dengan berita acara. Bertitik tolak dari ketentuan Pasal 83 ayat (3) huruf a dan Pasal 96 ayat (1), Bentuk putusan penetapan pada umumnya adalah serangkain berita acara dengan isi putusan tersebut, hal yang sama juga bisa ditemukan pada putusan perdata. Berita acara sidang beserta isi putusannya tidaklah dibuat terpisah, bentuk putusan Praperadilan ini hampir mirip dengan bentuk putusan volunter pada acara perdata. Dapat dibilang putusan Praperadilan ini juga bersifat deklarator, yang memiliki isi mengenai pernyataan tentang sah atau tidaknya penggeledahan, penyitaan, penangkapan, ataupun penahanan. Tentu tidak sama mengurangi sifat tentang ganti kerugian tersebut. ${ }^{16}$

\section{Akibat Hukum Putusan Praperadilan yang Menyatakan Penyidikan Tidak Sah}

Kewenangan yang dilimpahkan pada Mahkamah Agung guna mengawasi putusan Praperadilan haruslah dilaksanakan secara maksimal. Kententuan pengawasan Mahkamah Agung diatur pada Pasal 4 ayat (2) Peraturan Mahkamah Agung No. 4 Tahun 2016 yang mengatakan, bahwa wewenang Mahkamah Agung dalam melaksanakan fungsi pengawasannya kepada Praperadilan meliputi:

1. Pengawasan perbuatan dan tingkah laku para hakim dalam menjalankan tugasnya.

2. Meminta keterangan mengenai tata cara pemeriksaan Praperadilan.

3. Memberikan petunjuk, teguran, ataupun peringatan yang tampak perlu terhadap putusan Praperadilan yang menyimpang secara fundamental.

\footnotetext{
${ }_{15}$ M. Yahya Harahap I, Op.Cit.

${ }^{16}$ M. Yahya Harahap I, Op.Cit.
} 
Fungsi pengawasan Peraturan Mahkamah Agung No. 4 Tahun 2016 tidak saja berupa sebuah tindakan pengawasan pada tingkah laku para hakim dalam melaksanakan tugas serta kewenangannya. Tetapi, pengawasan dengan meminta keterangan mengenai teknis pemeriksaan serta pemberian petunjuk. Kemudian memberikan peringatan maupun teguran dilakukan setelah adanya suatu putusan Praperadilan yang dianggap menyimpang. Peraturan Mahkamah Agung No. 4 Tahun 2016 tidak menguraikan dan menjelaskan dengan gamblang frasa putusan Praperadilan yang dianggap menyimpang secara fundamental.

Penetapan pemberitahuan bahwa hasil penyidikan sudah lengkap bukan merupakan objek Praperadilan, sementara permasalahan pemberitahuan bahwa hasil penyidikan sudah lengkap adalah masalah terkait substansi perkara dan bukan aspek formil. Sebab disisi lain putusan Praperadilan tidaklah diberikan peluang untuk melakukan tindakan upaya hukum baik banding, kasasi, maupun peninjauan Kembali. ${ }^{17}$

\section{Mengenai Gugurnya Permohonan}

Dalam Putusan Mahkamah Konstitusi, menyimpulkan mengenai Pasal 50 ayat (2), (3), Pasal 52 ayat (1), (2), Pasal 137, dan Pasal 143 ayat (1) Kitab Undang-Undang Hukum Acara Pidana tidak bertentangan dengan Undang-Undang Dasar 1945. Mahkamah Konstitusi hanya menyatakan Pasal 82 ayat (1) huruf d Kitab Undang-Undang Hukum Acara Pidana inkonstitusional bersyarat sepanjang dimaknai permohonan Praperadilan gugur saat telah dimulainya sidang pertama terhadap pokok perkaranya. Demi kepastian hukum dan keadilan Mahkamah Konstitusi berpendapat, perkara Praperadilan dinyatakan gugur pada saat telah digelar sidang pertama terhadap perkara pokok atas nama terdakwa / pemohon dan sesuai dengan yang terkandung dalam Pasal 82 ayat (1) huruf d Kitab UndangUndang Hukum Acara Pidana ${ }^{18}$.

\footnotetext{
${ }^{17}$ Reda Manthovanni, 'Menilik Kebuntuan Putusan Praperadilan yang Dipandang Menyimpang' (Hukum Online, 2015), <www.hukumonline.com>, accessed 18 May 2020.

18 Agus Sahbani, "MK Perjelas Waktu Gugurnya Praperadilan", (Hukum Online, 2016), $<w w w . h u k u m o n l i n e . c o m>$, accessed 19 June 2020.
} 
Berdasarkan pada fakta hukum, Mahkamah Konstitusi menyatakan permohonan gugur jika pemohon meninggal dunia, karena subjek permohonan a quo sudah tidak ada, terlebih lagi tidak ada subjek hukum lain sehingga permohonan pengujian ketentuan pembatasan hak terdakwa dalam melakukan Praperadilan terhadap putusan yang mempunyai kekuatan hukum tetap tersebut, pantas dinyatakan gugur. ${ }^{19}$

Objek Praperadilan dapat ditinjau berdasarkan pada Pasal 2 Peraturan Mahkamah Agung No. 4 Tahun 2016 sebagai berikut:

1. Sah atau tidaknya penangkapan, penahanan, penghentian penyidikan atau penghentian penuntutan, penetapan tersangka, penyitaan dan penggeledahan.

2. Ganti kerugian dan atau rehabilitasi bagi seseorang yang perkara pidananya dihentikan pada tingkat penyidikan atau penuntutan.

Oleh karena itu, berdasarkan peninjauan objek Praperadilan pada Pasal 2 Peraturan Mahkamah Agung No. 4 Tahun 2016, hasil penyidikan yang telah selesai tidak termasuk kedalam objek Praperadilan.

\section{Ratio Decidendi Hakim Dalam Penetapan Hasil Penyidikan Yang Telah Selesai} Dinyatakan Tidak Sah Dan Tidak Mengikat Dalam Putusan Praperadilan No. 117/Pid.Prap/2017/Pn.Jkt.Sel

Pada tahun 2014, pemohon dengan Sdr.AzharUmar, dkk, terjadi suatu keributan pada kepengurusan PT. Multicon Indrajaya Terminal dan PT. Multiline Shipping Service, dikarenakan pemohon diduga telah melakukan tindakan pemalsuan akta autentik. Setelah beberapa kali diadakan pertemuan untuk menyelesaikan masalah yang ada, namun tak kunjung ada hasil penyelesaian sesuai dengan yang diharapkan oleh kedua belah pihak, pada akhirnya Sdr. Azhar Umar, dkk, secara sepihak membuat surat pemberhentian sementara pemohon dari posisi jabatan Direktur Utama PT. Multicon Indrajaya Terminal dan PT. Multiline Shipping Service, karena pemohon tidak merasa bersalah, maka selanjutnya pemohon menolak keras isi surat

\footnotetext{
19 Yusti Nurul Agustin, 'Pemohon Meninggal Dunia, MK Nyatakan Permohonan Gugur', (Mahkamah Konstitusi Republik Indonesia, 2014), <www.mkri.id>, accessed 21 July 2020.
} 
tersebut dan pemohon tetap melaksanakan rutinitas pekerjaan pemohon selaku Direktur Utama perusahaan.

Kronologis permasalahan sebagai alasan permohonan pemeriksaan Praperadilan adalah, terjadinya empat laporan polisi yang berasal dari pelapor yang sama, terlapor yang sama, peristiwa pidana yang dilaporkan sama, tempat dan waktu peristiwa pidana yang dilaporkan pun sama. Sehingga hal tersebut membuat ketidakpastian hukum terjadi kepada diri pemohon.

Keempat laporan polisi yang sama tersebut, dilaporkan oleh Sdr. Azhar Umar kepada pihak kepolisian sebagai berikut:

1. Akibat pemohon tidak menuruti surat pemberitahuan tersebut, pada 25 Agustus 2014, Sdr. Azhar Umar secara diam-diam melaporkan pemohon kepada Polda Metro Jaya, sesuai dengan Laporan Polisi No. LP/3007/VIII/2014/Dit. Reskrimum, dengan laporan dugaan tindak pidana menempatkan keterangan palsu dalam akta autentik sebagaimana dimaksud dalam pasal 266 Kitab UndangUndang Hukum Pidana, yang terjadi tanggal 25 Juni 2014 yang bertempatkan di Kantor Group Graha Kirana.

2. Setelah Laporan Polisi No. LP/3007/VIII/2014/Dit.Reskrimum dihentikan penyidikannya oleh Polda Metro Jaya, ternyata Sdr. Umar Azhar selaku pelapor merasa keberatan atas dikeluarkannya Surat Penghentian Penyidikan tersebut, kemudian secara diam-diam Sdr. Azhar Umar meminta pengacaranya untuk membuat laporan baru terhadap peristiwa pidana yang sama kepada Badan Reserse Kriminal Polri, sesuai Laporan Polisi No. LP/796/VI/2015/Bareskrim, tentang dugaan tindak pidana menyuruh menempatkan keterangan palsu kedalam akta autentik.

3. Pada 27 Juni 2017, Sdr. Azhar Umar membuat laporan polisi yang baru lagi, dikarenakan sesuai Laporan Polisi No. LP/796/VI/2015/Bareskrim dihentikan penyidikan dan penyelidikannya dikarenakan oleh tidak cukup bukti, pemohon dilaporkan kembali kepada Polda Metro Jaya dengan membuat Laporan Polisi No. LP/3081/VI/2017/PMJ/Dit.Reskrimum, tentang dugaan tindak pidana membuat surat palsu yang terjadi pada 25 Juni 2014 di kantor PT. Multicon 
Indrajaya Terminal.

4. Laporan Polisi No. LP/3081/VI/2017/PMJ/Dit.Reskrimum dihentikan juga proses penyidikan dan penyelidikannya dikarenakan tidak cukup bukti, kemudian pemohon dilaporkan kembali oleh Sdr. Bontor O.L. Tobing selaku kuasa dari Sdr. Azhar Umar, pada tanggal 8 September 2016 kepada Polres Jakarta Utara, dengan Laporan Polisi No. LP/1191/K/IX/2016/PMJ/RESJU, tentang dugaan tindak pidana menempatkan keterangan palsu dalam akta autentik sebagaimana yang dimaksud dalam Pasal 266 Kitab Undang-Undang Hukum Pidana.

\section{Analisis Kasus}

Berdasarkan pada Undang-Undang Republik Inonesia No. 8 Tahun 1981 tentang Hukum Acara Pidana, pengertian tentang Laporan, Penyidikan, Tersangka, Penangkapan, Penahanan, dan Penuntutan adalah sebagai berikut:

Pasal 1 angka 24 Kitab Undang-Undang Hukum Acara Pidana menyakatan, laporan merupakan pemberitahuan yang disampaikan oleh seorang karena hak atau kewajiban berdasarkan oleh undang-undang kepada pejabat yang berwenang tentang telah atau sedang atau diduga akan terjadi peristiwa pidana.

Pasal 1 angka 2 Kitab Undang-Undang Hukum Acara Pidana menyatakan bahwa, penyidikan adalah serangkaian Tindakan penyidik dalam hal dan menurut cara yang diatur dalam undang-undang ini untuk mencari serta mengumpulkan bukti yang dengan bukti itu membuat terang tentang tindak pidana yang terjadi dan guna menemukan tersangkanya.

Pasal 1 angka 14 Kitab Undang-Undang Hukum Acara Pidana menyatakan. tersangka merupakan seorang karena perbuatannya atau keadaannya, berdasarkan bukti permulaan patut diduga sebagai pelaku tindak pidana.

Pasal 1 angka 20 Kitab Undang-Undang Hukum Acara Pidana menyatakan bahwa, penangkapan merupakan suatu tindakan penyidik berupa pengekangan sementara waktu kebebasan tersangka atau terdakwa apabila terdapat cukup bukti guna kepentingan penyidikan atau penuntutan dan atau peradilan dalam hal serta menurut cara yang diatur dalam undang-undang ini. 
Pasal 1 angka 21 Kitab Undang-Undang Hukum Acara Pidana menyatakan, penahanan merupakan penempatakan tersangka atau terdakwa di tempat tertentu oleh penyidik atau penuntut umum atau hakim dengan penetapannya, dalam hal serta menurut cara yang diatur dalam undang-undang ini.

Pasal 1 angka 7 Kitab Undang-Undang Hukum Acara Pidana menyatakan, penuntutan merupakan tindakan penuntut umum untuk melimpahkan perkara pidana ke Pengadilan Negeri yang berwenang dalam hal dan menurut cara yang diatur dalam undang-undang ini dengan permintaan supaya diperiksa dan diputus oleh hakim di sidang pengadilan. ${ }^{20}$

Bertitik tolak dengan hal-hal diatas, mengenai dasar permohonan Praperadilan untuk memeriksa dan mengadili hal-hal berikut, tentang sah atau tidaknya tindakan termohon selaku penuntut umum dalam tingkat prapenuntutan dan penuntutan melakukan penahanan terhadap pemohon, berdasarkan hasil penyidikan berkas perkara dari laporan yang baru, yaitu Laporan Polisi No. LP/3081/VI/2017/PMJ/ Dit.Reskrimum, 27 Juli 2017 dengan surat perintah penyidikan No. SP.Sidik/1560/ VII/2017/Dit.Reskrimum, 11 Juli 2017, mengenai dugaan perbuatan tindak pidana membuat surat palsu sebagaimana dimaksudkan dalam Pasal 263 ayat (1) Kitab Undang-Undang Hukum Acara Pidana dan atau membuat akta autentik palsu sebagaimana dimaksudkan dalam Pasal 264 ayat (1) Kitab Undang-Undang Hukum Acara Pidana dan atau menyuruh menempatkan keterangan palsu kedalam akta autentik sebagaimana dimaksudkan Pasal 266 ayat (1) Kitab Undang-Undang Hukum Acara Pidana, yang terjadi pada tanggal 25 Juni 2014 di kantor PT. Multicon Indrajaya Terminal, dilaporkan oleh Sdr. Azhar Umar di Sentra Pelayanan Kepolisian Terpadu Polda Metro Jaya.

Sementara peristiwa pidana yang dilaporkan dalam penyidikan tersebut telah selesai dilaksanakan penyidikan dan penyelidikan oleh Penyidik Polda Metro Jaya dan Penyidik Bareskrim Polri, berdasarkan kepada hasil penyelidikan Laporan Polisi No. LP/3007/VIII/2014/Dit. Reskrimum, atas nama pelapor Sdr.

\footnotetext{
${ }^{20}$ Undang-Undang Republik Inonesia No. 8 Tahun 1981 tentang Hukum Acara Pidana.
} 
Azhar Umar dan Laporan Polisi No. LP/796/VI/2015/Bareskrim, atas nama pelapor Sdr. Azhar Umar.

Tindakan termohon selaku penuntut umum dalam tingkat Prapenuntutan menyatakan sudah lengkap berkas perkara dari hasil penyidikan laporan ketiga, sesuai Surat No. B-2832/0.1/Ep.1/09/2017 dengan perihal pemberitahuan hasil penyidikan perkara pidana atas nama tersangka Hiendra Soenjoto sudah lengkap. Padahal patut diketahui oleh termohon sebagaimana petunjuk yang sudah tertera dalam Surat No. B-5451/0.1/Ep.1/09/2017 mengenai hasil penyidikan belum lengkap dengan alasan bahwa penyidik Polda Metro Jaya tidak dapat melengkapi petunjuk yang telah diberikan, dengan perihal pengembalian berkas perkara atas nama tersangka Hiendra Soenjoto yang disangka melanggar ketentuan Pasal 263 ayat (1) Kitab Undang-Udang Hukum Pidana atau Pasal 294 ayat (1) Kitab UndangUdang Hukum Pidana atau Pasal 266 ayat (1) Kitab Undang-Udang Hukum Pidana untuk dilengkapi.

Penuntut umum mengeluarkan Surat Perintah Penahanan terhadap pemohon, berdasarkan suratnya No. B-117/0.1.11/Euh.2/9/2017, berasal dari hasil penyidikan laporan ketiga, patut diketahu bahwa laporan yang sama yaitu laporan pertama dan laporan kedua telah dihentikan penyidikannya (SP-3) oleh penyidik dikarenakan tidak adanya cukup bukti, sesuai Surat Ketetapan No. S/TAP/562/VII/2015/Dit. Reskrimum, tentang penghentian penyidikan dan Surat Badan Reserse Kriminal Polri Direktorat Tindak Pidana Ekonomi dan Khusus No. B/88/IX/2015/Dit. Tipideksus, dengan perihal pemberitahuan hasil penyelidikan.

Permintaan tuntutan diajukan oleh penuntut umum setelah pemeriksaan di sidang pengadilan dinyatakan selesai sesuai Pasal 182 ayat (1) Kitab UndangUndang Hukum Acara Pidana. Pemintaan tuntutan dibacakan setelah proses pembuktian selesai dilakukan. ${ }^{21}$

1. Mengenai sah atau tidaknya suatu tindakan penangkapan dan atau penahanan atas permintaan tersangka, keluarganya, ataupun pihak lain atas kuasa tersangka;

\footnotetext{
${ }^{21}$ Shanti Rachmadsyah, "Dakwaan Dengan Tuntutan" (Hukum Online, 2010) $<w w w$. hukumonline.com> accessed 10 June 2020.
} 
2. Mengenai sah atau tidaknya penghentian penyidikan, penghentian penuntutan atas permintaan demi tegaknya hukum dan keadilan;

3. Mengenai permintaan ganti kerugian atau rehabilitasi oleh tersangka, keluarganya, ataupun pihak lain atas kuasanya yang berperkara tidak diajukan ke pengadilan.

\section{Pengertian Ratio Decidendi dan Obiter Dicta}

Pengertian Ratio Decidendi atau pertimbangan hakim adalah suatu argumen ataupun alasan yang dipakai oleh hakim, sebagai pertimbangan hukum yang menjadi sebuah dasar sebelum memutus suatu perkara. Ratio Decidendi merupakan keputusan dewan hakim yang didasarkan kepada fakta-fakta materi. ${ }^{22}$ Ratio Decidendi inilah yang menunjukkan bahwa ilmu hukum merupakan ilmu yang bersifat preskriptif, bukan ilmu yang bersifat deskriptif, juga sebagai penafsiran hakim atau pertimbangan hakim yang dijadikan sebagai dasar dari pertimbangan oleh pembentuk undang-undang.

Fakta materiil menjadi fokus karena hakim maupun para pihak akan mencari dasar hukum yang tepat untuk diterapkan kepada kasus tersebut. Dalam menemukan Ratio Decidendi dalam suatu putusan, biasanya terdapat pada bagian-bagian tertentu, untuk sampai kepada salah satu putusan itu, hakim seharusnya menuliskan alasan-alasannya. Dalam hukum Indonesia yang menganut Civil Law System, maka Ratio Decidendi tersebut dapat ditemukan pada konsideran "Menimbang" pada "Pokok Perkara". ${ }^{23}$ Tidak dapat disangkal bahwa tindakan-tindakan hakim yang memberikan alasan-alsan yang mengarahkan kepada putusan merupakan tindakan yang menafsirkan suatu undang-undang. ${ }^{24}$

Pada umumnya fungsi dari Ratio Decidendi sendiri adalah sebagai sarana mempresentasikan pokok-pokok pemikiran tentang permasalahan konflik hukum antara seseorang dengan orang lain, atau antara masyarakat dengan

${ }^{22}$ LP.M Ranuhandoko, Terminologi Hukum Inggris-Indonesia, (Sinar Grafika 2003).[475].

${ }_{23}$ Peter Mahmud Marzuki, Penelitian Hukum (Kencana 2007).[119].

${ }^{24}$ Achmad Mu'as, 'Inkonsistensi Putusan Mahkamah Konstitusi Atas Penyelenggaraan Pemilu Serentak', Skripsi Program Studi Ilmu Hukum (Universitas Airlangga 2015).[57]. 
pemerintahan terhadap kasus-kasus kontraproduktif untuk menjadi replika dan duplika percontohan, terutama menyangkut baik dan buruknya sistem penerapan dan penegakan hukum, sikap tindakan aparatur hukum, dan lembaga peradilan..$^{25}$

Ratio Decidendi yang merupakan bagian pertimbangan sebagai dasar atau alasan yang menentukan diambilnya suatu keputusan yang dirumuskan dalam amar. Bagian pertimbangan ini tidak dapat dipisahkan dari amar putusan dan memiliki kekuatan mengikat secara hukum yang dapat dirumuskan sebagai kaidah hukum. ${ }^{26}$ Jadi, Ratio Decidendi dalam putusan hakim itu dinyatakan dalam suatu proposisi hukum. Proposisi dalam konteks ini adalah premis yang memuat pertimbangan hakim. Proposisi ini dapat diungkapkan secara eksplisit atau implisit. Hal ini menginatkan pada definisi lain tentang Ratio Decidendi, yaitu setiap aturan yang tersurat atau tersirat yang diterapkan oleh hakim sebagai langkah yang perlu dilakukan dalam mencapai kesimpulan. Putusan hakim terdahulu merupakan sumber hukum utama yang mutlak untuk dicermati Ketika menghadapi suatu perkara serupa. Fakta-fakta disini harus merupakan fakta material yang memang dipakai sebagai dasar oleh hakim saat membangun pertimbangan-pertimbangan menuju pada kesimpulan. ${ }^{27}$

Obiter Dicta dalam konteks hukum ini mengacu pada bagian putusan hukum yang tidak pokok atau tidak terkait dengan substansi utama. Obiter Dicta hanyalah bersifat persuasif, pernyataan yang tidak pokok ataupun hanya mengacu pada perandaian ataupun isu hukum yang tidak terkait. Obiter Dicta dapat mengikat secara hukum, jika pengadilan dalam perkara lain mengutip Obiter Dicta dari putusan sebelumnya dan menjadikan hal tersebut sebagai Ratio Decidendi. ${ }^{28}$

\footnotetext{
${ }^{25}$ Abraham Amos H.F, 'Legal Opinion Teoritis \& Empirisme', (Grafindo Persada 2007).[34].

${ }^{26}$ Maruarar Siahaan, Hukum Acara Mahkamah Konstitusi Republik Indonesia, (Konstitusi Press 2005).[205].

${ }^{27}$ Shidarta, 'Ratio Decidendi dan Kaidah Yurisprudensi',(Bina Nusantara, 2019) <www.business-law.binus.ac.id> accessed 21 July 2020.

${ }^{28}$ Meika Arista, 'Kapan Pertimbangan Putusan Mahkamah Konstitusi Dikatakan Mengikat dan Tidak Mengikat?', (Hukum Online, 2019) <www.hukumonline.com> accessed 6 June 2020.
} 


\section{Pertimbangan Hakim Dalam Menjatuhkan Putusan}

Berdasar pada asas praduga tak bersalah yang dianut oleh hukum di Indonesia, maka seseorang belum bisa dinyatakan bersalah sebelum mendapatkan putusan hakim yang telah inkrah. Sebelum hakim menjatuhkan putusan, maka harus dilakukan pembuktian terlebih dahulu dalam pengadilan berdasar pada proses acara dalam perkara pidana yang berdasar pada Kitab Undang-Undang Hukum Acara Pidana. Pembuktian dalam hal ini menjadi salah satu alasan hakim berkeyakinan putusan seperti apa yang seharusnya dijatuhkan untuk terdakwa, untuk menjatuhkan putusan dalam suatu perkara, maka hakim wajib melakukan pertimbangan-pertimbangan dengan seksama. ${ }^{29}$ Pertimbangan hakim dalam putusan harus mengetahui aspek teoritik, pandangan doktrin, yurisprudensi, dan posisi kasus yang sedang ditangani. Setelah pencantuman unsur-unsur tersebut, kemudian dipertimbangkan hal-hal lain yang memberatkan dan meringankan. ${ }^{30}$

Bahwa segala tindakan termohon dalam menetapkan hasil penyidikan yang telah selesai terhadap berkas perkara hasil penyidikan atas Laporan Polisi ketiga adalah melanggar dengan ketentuan Pasal 110 ayat (2) dan (3) Kitab UndangUndang Hukum Acara Pidana, adapun pelanggaran yang dilakukan termohon dalam menetapkan hasil penyidikan yang telah selesai dikarenakan penyidik tidak melengkapi petunjuk sesuai dengan permintaan termohon sebagaimana tertulis dalam, surat No. B-5451/0.1.1/EP.1/09/2017, 6 September 2017.

Bahwa seharusnya apabila penyidik tidak dapat melengkapi petunjuk yang diberikan termohon, maka jalan satu-satunya adalah termohon mengembalikan berkas perkara tersebut kepada penyidik, hal ini diatur dalam Peraturan Jaksa Agung Republik Indoesia No. PER-036/A/JA/09/2011, mengenai Standar Operasional Prorosedur Penanganan Perkara Tindak Pidana Umum, pada bagian 3 penetilian berkas perkara Pasal 11 ayat (5), menyatakan: Dalam hal Penuntut

\footnotetext{
${ }^{29}$ Syarifah Dewi Indawati S, 'Dasar Pertimbangan Hukum Hakim Menjatuhkan Putusan Lepas Dari Segala Tuntutan Hukum Terdakwa Dalam Perkara Penipuan’ Bagian Hukum Acara Fakultas Hukum Universitas Sebelas Maret Vol. 5 No. 2.[275].

${ }^{30}$ Juanda Maulud Akbar, "Pertimbangan Hakim", <www.wordpress.com>, , accessed 10 June 2020.
} 
Umum menerima kembali berkas perkara yang sebelumnya dinyatakan belum lengkap sebagaimana dimaksud ayat (3), tetapi tidak dilengkapi sesuai petunjuk, padahal tersebut berpengaruh terhadap pembuktian di persidangan, maka Penuntut Umum mengembalikan berkas perkara kepada Penyidik. Bahwa termohon tidak mengembalikan berkas perkara tersebut kepada Penyidik, maka termohon telah melanggar Standar Operasional Prorosedur Penanganan Perkara Tindak Pidana Umum, yang dibuat oleh termohon sendiri.

Bahwa dengan demikian, penetapan hasil penyidikan yang telah selesai yang dikeluarkan oleh termohon jelas sangat melanggar Ketentuan Pasal 110 ayat (1), (2), dan (3) Kitab Undang-Undang Hukum Acara Pidana dan Peraturan Jaksa Agung Republik Indoesia No. PER-036/A/JA/09/2011, mengenai Standar Operasional Prorosedur Penanganan Perkara Tindak Pidana Umum, pada bagian 3 penetilian berkas perkara Pasal 11 ayat (5), maka seharusnya Hakim Tunggal Praperadilan menyatakan bahwa hasil penyidikan yang telah selesai sebagaimana tertera dalam Surat No. B-2832/0.1.1/Ep.1/ 09/2017, 19 September 2017 Perihal: Pemberitahuan hasil Penyidikan perkara pidana atas nama tersangka Hiendra Soenjoto sudah lengkap, haruslah dinyatakan tidak sah dan tidak mempunyai kekuatan hukum mengikat Bahwa karena Penetapan hasil penyidikan yang telah selesai tidak sah dan tidak mempunyai kekuatan hukum mengikat, maka berkas perkara berdasarkan hasil penyidikan atas Laporan Polisi No. LP/3081/VI/2017PMJ/Dit.Reskrimum, 27 Juni 2017, atas nama Pelapor Sdr. Azhar Umar, laporan ketiga yang dipergunakan oleh termohon sebagai dasar penuntutan di Pengadilan, dibarengi dengan upaya paksa menetapkan termohon sebagai tersangka dan ditahan, maka seharusnyalah dinyatakan penetapan Tersangka dan Penahanan terhadap termohon dinyatakan tidak sah dan tidak mempunyai kekuatan hukum yang mengikat.

Bahwa dikarenakan penetapan pemohon sebagai tersangka dan ditahan tidak sah dan tidak mempunyai kekuatan hukum mengikat, maka semestinya dinyatakan memerintahkan termohon mengeluarkan pemohon dari tahanan, serta memulihkan harkat dan martabat pemohon kepada keadaan semula. 


\section{Pertimbangan Yuridis}

Pertimbangan Yuridis merupakan pertimbangan hukum yang menjadi landasan sebelum memutus suatu perkara, hakim akan melihat fakta-fakta dalam proses persidangan yang merupakan sebuah konklusi kumulatif dari keterangan saksi-saksi, keterangan terdakwa, serta barang bukti. Fakta-fakta yang dihadirkan berorientasi dari lokasi, waktu kejadian, dan modus operandi tentang bagaimana tindak pidana tersebut dilakukan. ${ }^{31}$

Adapun pertimbangan yuridis yang digunakan oleh Hakim Tunggal Effendi Muchtar dalam memutus perkara ini adalah sebagai berikut:

1. Penyidik tidak dapat melengkapi syarat formil berkas perkara, yaitu tidak melakukan penyitaan dan tidak melampirkan putusan kasasi dengan No. 2775/K/Pdt/2016 dalam berkas perkara sesuai petunjuk termohon. Padahal sangat berpengaruh dalam pembuktian di sidang Pengadilan;

2. Penyidik tidak dapat melengkapai syarat formil berkas perkara yaitu, tidak melakukan pemeriksaan sebagai saksi terhadap pihak dari Tentara Nasional Indonesia Angkatan Laut yang menandatangani surat perjanjian tersebut. Padahal sangat berpengaruh dalam pembuktian di sidang pengadilan;

3. Penyidik tidak dapat melengkapi petunjuk termohon, tentang peranan $\mathrm{H}$. Zainuddin, S. H selaku Notaris disertai dengan alat bukti yang sah dalam mencantumkan pasal penyertaan Pasal 55 ayat (1) Kitab Undang-Undang Hukum Pidana pada berkas perkara, padahal sangat berpengaruh dalam pembuktian di sidang pengadilan;

4. Banyak lagi hal-hal yang tidak dapat dilengkapi penyidik terhadap petunjuk termohon tersebut, pada saat acara pembuktian nanti pemohon akan membuktikan seluruh kekurangan yang belum dilengkapi oleh penyidik didalam petunjuk yang diberikan oleh termohon tersebut.

Ratio Decidendi hakim dalam penetapan hasil penyidikan yang telah selesai dinyatakan tidak sah dan tidak mengikat dalam putusan Praperadilan No. 117/Pid. Prap/2017/PN.Jkt.Sel berdasarkan pada Putusan Mahkamah Konstitusi Indonesia No. 21/PUU-XII/2014 tentang Pengujian Materiil Undang-Undang No. 8 Tahun 1981 dan Yurisprudensi Putusan Pengadilan Negeri Jakarta Selatan No. 04/Pid. Prap/2015/PN.Jkt.Sel.

\footnotetext{
31 Juanda Maulud Akbar, Loc.cit.
} 


\section{Kesimpulan}

1. Peninjauan objek Praperadilan dapat dilakukan berdasarkan pada Pasal 2 Peraturan Mahkamah Agung No. 4 Tahun 2016 sebagai berikut:

a. Sah atau tidaknya penangkapan, penahanan, penghentian penyidikan atau penghentian penuntutan, penetapan tersangka, penyitaan dan penggeledahan.

b. Ganti kerugian dan atau rehabilitasi bagi seseorang yang perkara pidananya dihentikan pada tingkat penyidikan atau penuntutan.

Oleh karena itu, berdasarkan peninjauan objek Praperadilan pada Pasal 2 Peraturan Mahkamah Agung No. 4 Tahun 2016, hasil penyidikan yang telah selesai tidak termasuk kedalam objek Praperadilan sementara permasalahan hasil penyidikan sudah lengkap adalah masalah terkait substansi perkara dan bukan aspek formil.

2. Ratio Decidendi hakim dalam penetapan hasil penyidikan yang telah selesai dinyatakan tidak sah dan tidak mengikat dalam putusan Praperadilan No. 117/ Pid.Prap/2017/PN.Jkt.Sel berdasarkan kepada:

a. Putusan Mahkamah Konstitusi Indonesia Nomor: 21/PUU-XII/2014 tentang Pengujian Materiil Undang-Undang No. 8 Tahun 1981 tentang Hukum Acara Pidana terhadap Undang-Undang Dasar 1945.

b. Yurisprudensi Putusan Pengadilan Negeri Jakarta Selatan Nomor: 04/Pid. Prap/2015/PN.Jkt.Sel yang memperluas objek Praperadilan yang belum diatur dalam pasal 77 s/d 83 Kitab Undamg-Undang Hukum Acara Pidana mengenai segala tindakan penyidik dalam melaksanakan proses penyidikan, tindakan penuntut umum dalam melaksanakan proses penuntutan, dan tentang lembaga hukum yang memiliki wewenang untuk menguji sah atau tidaknya tindakan penyidik dan segala tindakan penuntut umum.

\section{Daftar Bacaan}

\section{Buku}

Andi Hamzah, Hukum Acara Pidana Indonesia (Sinar Grafika 2013).

H.F. Abraham Amos, Legal Opinion Teoritis \& Empirisme (Grafindo Persada 2007). 
Lilik Mulyadi, Hukum Acara Pidana, Normatif, Teoritis, Praktik, dan Permasalahannya (Alumni 2007).

LP.M Ranuhandoko, Terminologi Hukum Inggris-Indonesia (Sinar Grafika 2003).

Maruarar Siahaan, Hukum Acara Mahkamah Konstitusi Republik Indonesia (Konstitusi Press 2005).

M. Yahya Harahap, Pembahasan Permasalahan dan Penerapan KUHAP Penyidikan dan Penuntutan (Sinar Grafika 2003).

, Pembahasan Permasalahan dan Penerapan KUHAP Pemeriksaan Sidang Pengadilan, Banding, Kasasi, dan Peninjauan Kembali (Sinar Grafika 2009).

Nikolas Simanjuntak, Acara Hukum Pidana Dalam Sirkus Hukum (Ghalia Indonesia 2009).

Peter Mahmud Marzuki, Penelitian Hukum (Prenada Media Group 2005).

\section{Jurnal}

Maskur Hidayat, 'Pembaharuan Hukum Terhadap Lembaga Praperadilan Melalui Putusan Pengadilan' (2015) Yuridika Vol 30 No 3.

Syarifah Dewi Indrawati, 'Dasar Pertimbangan Hukum Hakim Menjatuhkan Putusan Lepas Dari Segala Tuntutan Hukum Terdakwa Dalam Perkara Penipuan' Bagian Hukum Acara Fakultas Hukum Universitas Sebelas Maret Vol. 5 No. 2.

Achmad Mu'as, Inkonsistensi Putusan Mahkamah Konstitusi Atas Penyelenggaraan Pemilu Serentak (2015) Skripsi Program Studi Ilmu Hukum Universitas Airlangga.

\section{Laman}

Yusti Nurul Agustin, "Pemohon Meninggal Dunia, MK Nyatakan Permohonan Gugur", <www.mkri.id>, diakses pada tanggal 21 Juli 2020.

Al-Khawarizmi, Damang Avveroes, "Penyelidikan dan Penyidikan", $<w w w$. negarahukum.com>, diakses pada tanggal 19 Juni 2020.

Ari, Ivan, "Prinsip Permohonan", <hukumacara.com $>$, diakses pada tanggal 10 Juni 2020. 
Arista, Meika, "Kapan Pertimbangan Putusan Mahkamah Konstitusi Dikatakan Mengikat dan Tidak Mengikat?", <www.hukumonline.com>, diakses pada tanggal 6 Juni 2020.

Akbar, Juanda Maulud, "Pertimbangan Hakim”, <www.wordpress.com>, diakses pada tanggal 10 Juni 2020.

Hasanah, Sovia, "Gelar Perkara dan Seluk Beluknya", <www.hukumonline.com>, diakses pada 2 Agustus 2020.

Manthovanni, Reda, "Menilik Kebuntuan Putusan Pt/raperadilan yang Dipandang Menyimpang", <www.hukumonline.com>, diakses pada tanggal 18 Mei 2020.

Pramesti, Tri Jata Ayu, "BAP Dibuat Berdasarkan Penyidikan yang Tidak Sah”, $<w w w . h u k u m o n l i n e . c o m>$, diakses pada tanggal 13 Mei 2020.

Pramesti, Tri Jata Ayu, "Hakim Tunggal dan Objek Praperadilan Pasca Putusan MK”, <www.hukumonline.com>, diakses pada 2 Agustus 2020.

Rachmadsyah, Shanti, "Dakwaan Dengan Tuntutan”, <www.hukumonline.com>, diakses pada tanggal 10 Juni 2020.

Shidarta, "Ratio Decidendi dan Kaidah Yurisprudensi”, www.business-law.binus. ac.id, 4 Maret 2019, h. 1, diakses pada tanggal 21 Juli 2020. 